\title{
THEORETICAL ASPECTS OF KEY TRENDS IN THE DEVELOPMENT OF THE INSURANCE MARKET OF UKRAINE
}

\section{ТЕОРЕТИЧНІ АСПЕКТИ КЛЮЧОВИХ ТЕНДЕНЦІЙ РОЗВИТКУ СТРАХОВОГО РИНКУ УКРАЇНИ}

\begin{abstract}
The modern insurance market is formed in the conditions of gradual increase of basic macroeconomic indicators, in particular growth of the gross domestic product, establishment of low rates of inflation, maintenance of the stability of national and foreign currency that allows providing its dynamic and complex development. Insurance can be a mechanism that can significantly reduce government spending. Insurers can partially replace state insurance programs. This reduces the burden on the social assistance system, leaving the government with resources for the most essential social protection goals. Moreover, insurance can mitigate the negative economic impact of a natural disaster by reducing the need for government financial intervention. The purpose of this study is to analyze the theoretical and analytical features of the insurance market of Ukraine and the formation of key recommendations for its transformation.

Key words: insurance, insurance market, insured, insurer, personal insurance, health insurance, insurance payments.
\end{abstract}

Современный страховой рынок формируется в условиях постепенного повышения базовых макроэкономических показателей, в частности рост валового внутреннего продукта, установления низких темпов инфрляции, обеспечение стабильности национальной и иностранной валюты, что позволяет обеспечить динамичное $u$ комплексное его развитие. Страхование может стать тем механизмом, который позволит значительно снизить объем государственных расходов. Страховщики могут частично заменить государственные программы страхования. Это уменьшает нагрузку на систему социальной помощи, а также оставляет государству дополнительные ресурсы для достижения важнейших и необходимых целей социального обеспечения населения. Также, страхование должно обеспечивать сокращение уровня общего негативного экономического и социального влияния от общенационального уровня бедности, уменьшать потребность в дополнительном фринансовом вмешательстве государства. Целью данного исследования является анализ теоретических и аналитических особенностей функционирования страхового рынка Украины и формирования ключевых рекомендаций по его трансфрормации.

Ключевые слова: страхование, страховой рынок, страхователь, страховщик, личное страхование, медицинское страхование, страховые выплаты.

of the Private Joint-Stock Company

Insurance Company VUSO

Недостатній рівень довіри українців до вітчизняного страхового ринку, викликаний низьким рівнем надійності страхових компаній, частими випадками шахрайських дій з їхньої сторони відносно клієнтів, які супроводжувалися невиплатою відповідних страхових премій тощо, $\epsilon$ однією із головних причин його відставання за основними показниками ефеективності від решти ринків фінансового сектору, зокрема, банківського. У статті розглянуто ключові аспекти страхового ринку Украӥни. В розрізі поставленої мети дослідження, яка полягає в проведенні комплексного дослідження теоретичних та аналітичних особливостей фрункціонування страхового ринку України та фоормування рекомендацій щодо його транссрормації, було запропоновано для ії досягнення дотримуватись наступних дій: страхувальники повинні розробляти та впроваджувати такі страхові продукти і послуги, які б носили заохочувальний характер, та сприяли підвищенню стандартів транспарентності і відповідності міжнародним практикам; за рахунок підвищення вимог до достатності капіталу страхових компаній уникати псевдострахування; залучення страхових компаній до сектору недержавного пенсійного забезпечення, а також актуалізувати їхню участь в обов'язковому медичному страхуванню; оновити існуюче та розробити нове нормативне забезпечення відповідних законодавчих актів, якідозволяли буникати ряд дій протиправного характеру. Позитивний результат від перерахованих рекомендацій щодо фуннкціонування вітчизняного страхового ринку може бути отриманий виключно за рахунок координаційної взаємодії між страховими компаніями і державою. В чілому, відповідно до отриманих результатів проведеного аналітичного дослідження, кількість страхових компаній в динаміці протягом останніх п'яти років скорочується на 128 од. та на кінець 2019 року становить 233. Кількість страхових компаній типу «Lіfе» зменшилась з 49 у 2015 році до 23 у 2019 році, що зумовлено проведенням реформи «очищення» страхового ринку від страхових компаній, визнаних неплатоспроможними. Проте, незважаючи на представлену тенденцію щодо зміни їх номінальної кількості, якість наданих ними послуг покращилась. Також було виявлено, що найпоширенішим видом особистого страхування є страхування від нещасних випадків на транспорті. Ключові слова: страхування, страховий ринок, страхувальник, страховик, особисте страхування, медичне страхування, страхові виплати.

Formulation of the problem. Unfavorable market conditions complicate the current stage of development of the personal insurance segment. The effects of the economic crisis of 2014-2015 and inconsistency of reforms in the social sphere delay the solution of such vital issues as deteriorating demographics, disability, high morbidity, accidents, common accidents, medical care, poor solvency of the population. In addition to economic destabilization, the spread of the COVID19 pandemic has a significant impact on the level of personal security. In many countries worldwide, insurance companies have expanded their insurance coverage to cover the cost of treatment or compensation for deaths through COVID-19. In the countries most affected by the adverse effects of the pandemic (China, Italy, USA), the insurance industry has significantly shifted to providing support to people affected by this disease. Therefore, the insurance market needs to be reformed to provide comprehensive and systematic consumer support.

Analysis of recent research and publications. Domestic scientists were engaged in research of essence and features of functioning personal insurance and research of the basic tendencies of the insurance market development in Ukraine, including Botvina N. O. [1], Onyshko S. V. [7], Philipenko A. V. [9], 
Hrynchyshyn Ya. M. [3], Malikova I. P. [6], Zolotarova O. V. [5], Vremenko L. V. and Derkach K. I. [2], Zhuravka O. S., Pakhnenko O. M. and Sukhomlin A. A. [4] and others.

The purpose of this study is to analyze the theoretical and analytical features of the insurance market of Ukraine and the formation of key recommendations for its transformation.

Presenting main material. A critical definition that always goes hand in hand when determining the economic essence of the insurance process is the concept of reliability. Many functional features of this category manifest it:

- stable development of entrepreneurship, trade, and production directly depends on the availability of insurance products and services;

- innovation progress will be faster in the country whose insurance market will be able to provide an appropriate level of insurance guarantees to entrepreneurs who develop startup ideas and implement new projects;

- affordable insurance of movable or immovable property significantly reduces the risks of complete or partial loss of financial capacity of the entity;

- helps reduce public spending, which reduces the burden on the country's social security system.

The sectoral insurance market is representing as follows (Fig. 1). As you can see, in the standard form, the insurance market consists of three sectors: the authorized body that monitors the insurance market, directly insurance companies (insurers), and insurance and non-insurance intermediaries.

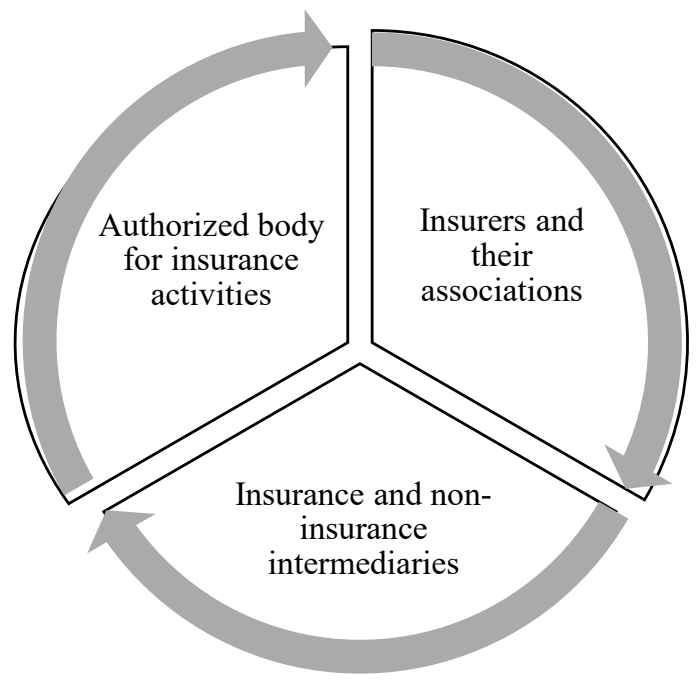

Fig. 1. The sectoral structure of the insurance market
Personal insurance is a critical element of social insurance. In current conditions, the personal insurance industry has positive development dynamics, which indicates an increase in consumer demand.

To analyze the state of development of the personal insurance market, we analyze the dynamics of changes in the number of insurance companies (Table 1).

According to the table. 1, the number of insurance companies in the dynamics decreases by 128 units. And at the end of 2019 is 233 insurance companies. The number of life insurance companies is decreasing from 49 in 2015 to 23 in 2019. It is due to the purification of the insurance market from insolvent insurance companies. Despite the decrease in their absolute number, the quality of services provided has improved.

The leading indicators that characterize the personal insurance market are the volume of net premiums and payments (Table 2).

After analyzing the table. 2, note that the volume of net insurance premiums in the dynamics increases by $77.08 \%$. At the end of 2019 amounted to UAH 39,586 million, while net personal insurance premiums increased by $139.83 \%$, indicating this market segment's development. The share of private insurance premiums in the total insurance premiums increased from $23.94 \%$ in 2015 to $29.66 \%$ in 2019. Net insurance payments in 2019 increased to UAH 14040.5 million, 84.68\% more than in the base year and $12.93 \%$ more than in the previous period. The $91.33 \%$ increase in personal insurance payments indicates that insurance companies have performed their duties correctly. The share of private insurance payments in the total insurance payments increased from $26.09 \%$ in 2015 to $27.03 \%$ in 2019 .

Given the specifics of the domestic insurance market and the development of trends in this sector, it is essential to follow the following recommendations to achieve a positive result:

- policyholders should develop and implement insurance products and services that are encouraging and help raise standards of transparency and compliance with international practices;

- by increasing the capital adequacy requirements of insurance companies to avoid pseudoinsurance;

- involvement of insurance companies in the private pension sector, as well as to update their participation in compulsory health insurance;

Table 1

Dynamics of the number of insurance companies in Ukraine for 2015-2019

\begin{tabular}{|l|c|c|c|c|c|c|c|}
\hline \multirow{2}{*}{ Type of the insurance company } & \multicolumn{4}{c|}{ Year } & \multicolumn{3}{c|}{ Deviation, +/- } \\
\cline { 2 - 9 } & $\mathbf{2 0 1 5}$ & $\mathbf{2 0 1 6}$ & $\mathbf{2 0 1 7}$ & $\mathbf{2 0 1 8}$ & $\mathbf{2 0 1 9}$ & $\mathbf{2 0 1 9 / 2 0 1 5}$ & $\mathbf{2 0 1 9 / 2 0 1 8}$ \\
\hline "Life" & 49 & 39 & 39 & 30 & 23 & -26 & -7 \\
\hline "non-Life" & 312 & 271 & 255 & 251 & 210 & -102 & -41 \\
\hline Total & 361 & 310 & 294 & 281 & 233 & -128 & -48 \\
\hline
\end{tabular}


The share of personal insurance in the insurance market of Ukraine

Table 2

\begin{tabular}{|l|c|c|c|c|c|c|c|}
\hline \multicolumn{1}{|c|}{ Indicator } & \multicolumn{3}{c|}{ Year } & \multicolumn{2}{c|}{ Growth rate, \% } \\
\cline { 2 - 8 } & $\mathbf{2 0 1 5}$ & $\mathbf{2 0 1 6}$ & $\mathbf{2 0 1 7}$ & $\mathbf{2 0 1 8}$ & $\mathbf{2 0 1 9}$ & $\mathbf{2 0 1 9 /}$ & $\mathbf{2 0 1 9 /}$ \\
\cline { 3 - 8 } & 22354,7 & 26463,8 & 28494,4 & 34424,3 & 39586 & 77,08 & $\mathbf{2 0 1 8}$ \\
\hline $\begin{array}{l}\text { Net insurance premiums } \\
\text { total, UAH mIn }\end{array}$ & 5352,4 & 6860,3 & 7962,2 & 10211,5 & 12836,9 & 139,83 & 25,71 \\
\hline $\begin{array}{l}\text { Net personal insurance } \\
\text { premiums, UAH mln }\end{array}$ & 23,94 & 25,92 & 27,94 & 29,66 & 32,43 & 35,44 & 9,32 \\
\hline $\begin{array}{l}\text { Share of personal } \\
\text { insurance premiums } \\
\text { in the total amount } \\
\text { of insurance premiums,\% }\end{array}$ & 7602,8 & 8561,1 & 10256,7 & 12432,6 & 14040,5 & 84,68 & 12,93 \\
\hline $\begin{array}{l}\text { Net insurance payments } \\
\text { in total, UAH mln }\end{array}$ & 1983,3 & 2138,7 & 2681,9 & 3336,1 & 3794,7 & 91,33 & 13,75 \\
\hline $\begin{array}{l}\text { Net insurance payments } \\
\text { of personal insurance, UAH mln. }\end{array}$ & 26,09 & 24,98 & 26,15 & 26,83 & 27,03 & 3,60 & 0,72 \\
\hline $\begin{array}{l}\text { Share of personal insurance } \\
\text { payments in the total amount } \\
\text { of net insurance payments, } \%\end{array}$ & & & & & & \\
\hline
\end{tabular}

- to update the existing and develop new normative support of the corresponding legislative acts, which would avoid some actions of the illegal character.

Conclusions and suggestions. Given the current challenges facing the insurance sector, an integral part of its successful operation is introducing a new model of financial support for the population, which would ensure the efficient allocation of financial resources and reduce informal payments. Considering the conditions of the transition to market relations, voluntary insurance is updated. It is based on building a relationship of trust between the insurer and the insured. The importance of establishing partnerships between key insurance entities is the key to building an influential insurance segment.

\section{REFERENCES:}

1. Botvina N.O. (2016) Stan ta tendentsiyi finansovoyi bezpeky u strakhovomu sehmenti Ukrayiny [Status and trends of financial security in the insurance segment of Ukraine]. Biznes-navihator, no. 1 (38), pp. 52-57.

2. Vremenko L. V., Derkach K. I. (2019) Suchasni tendentsiyi rozvytku konkurentsiyi ta monopolizatsiyi na vitchyznyanomu strakhovomu rynku [Current trends in competition and monopolization in the domestic insurance market]. Biznes Inform, no. 3, pp. 358-364.

3. Hrynchyshyn Ya. M., Prokopyuk A. V. (2017) Stan ta perspektyvy rozvytku strakhovoho rynku Ukrayiny [Status and prospects of development of the insurance market of Ukraine]. Molodyy vchenyy, no. 3, pp. 622-626.

4. Zhuravka O. S., Pakhnenko O. M., Sukhomlyn A. A. (2019) Doslidzhennya kontsentratsiyi ta konkurentsiyi na strakhovomu rynku Ukrayiny [Study of concentration and competition in the insurance market of Ukraine]. Visnyk Sums'koho derzhavnoho universytetu. Seriya «Ekonomika», no. 1, pp. 26-35.

5. Zolotarova O. V. (2017) Klyuchovi tendentsiyi ta priorytety rozvytku rynku strakhovykh posluh $\vee$ Ukray- ini [Key trends and priorities for the development of the insurance services market in Ukraine]. Ekonomika i derzhava, no. 11, pp. 413-420.

6. Malikova I. P. (2017) Otsinka kontsentratsiyi strakhovoho rynku Ukrayiny,yiyi zv"yazok z protsesamy monopolizatsiyi ta konkurentsiyi [Assessment of the concentration of the insurance market of Ukraine, its connection with the processes of monopolization and competition]. Naukovyy visnyk Khersons'koho derzhavnoho universytetu. Seriya «Ekonomichni nauky», vol. 23. Part 3, pp. 76-79.

7. Onyshko S. V., Shevchuk Yu. V. (2016) Problemy finansuvannya i perspektyvy rozvytku medychnoho strakhuvannya $\vee$ Ukrayini [Problems of financing and prospects of health insurance development in Ukraine]. Intelekt XXI, no. 5, pp. 158-162.

8. Reytynh strakhovykh kompaniy Ukrayiny. Forynshurer: strakhovanye. Available at: https://forinsurer.com/ ratings/nonlife/18/12/94/ (accessed 10 March 2021).

9. Philipenko A. V., Olvinska Yu. V. (2018) Porivnyal'nyy analiz medychnoho strakhuvannya $v$ krayinakh svitu [Comparative analysis of health insurance in the world]. Statystyka - instrument sotsial'noekonomichnykh doslidzhen': mater. konf. Odesa, ONEU, pp. 91-97.

\section{БІБЛІОГРАФІЧНИЙ СПИСОК:}

1. Ботвіна Н.О. Стан та тенденції фрінансової безпеки у страховому сегменті України. Бізнес-навігаmop. 2016. № 1 (38). С. 52-57.

2. Временко Л.В., Деркач К.І. Сучасні тенденції розвитку конкуренції та монополізації на вітчизняному страховому ринку. Бізнес Інфрорм. 2019. № 3. C. $358-364$.

3. Гринчишин Я. М., Прокопюк А. В. Стан та перспективи розвитку страхового ринку України. Молодий вчений. 2017. № 3. С. 622-626.

4. Журавка О.С., Пахненко О.М., Сухомлин А.А. Дослідження концентрації та конкуренції на страховому ринку України. Вісник Сумського державного університету. Серія «Економіка». 2019. № 1. С. 26-35. 
5. Золотарова О.В. Ключові тенденції та пріоритети розвитку ринку страхових послуг в Україні. Економіка і держава. 2017. № 11. С. 413-420.

6. Малікова І.П. Оцінка концентрації страхового ринку України,ії зв'язок з процесами монополізації та конкуренції. Науковий вісник Херсонського державного університету. Серія «Економічні науки». 2017. Вип. 23.Частина 3. С. 76-79.

7. Онишко С.В., Шевчук Ю.В. Проблеми фрінансування і перспективи розвитку медичного стра- хування в Україні. Інтелект XXI. 2016. № 5. C. $158-162$.

8. Рейтинг страхових компаній України. Фориншуpep: страхование. URL: https://forinsurer.com/ratings/ nonlife/18/12/94/ (дата звернення: 10.03.2021).

9. Філіпенко А.В., Ольвінська Ю.О. Порівняльний аналіз медичного страхування в країнах світу. Статистика - інструмент соціально-економічних досліджень: матер. конф. Одеса : ОНЕУ. C. 91-97. 